Endocrinol. Japon. 1984, 31 (3), 369-374

\title{
NOTE
}

\section{Comparison of LATS Activity and TSH Receptor Antibody in Graves' Disease}

\author{
Yoshihiro KAJITA, Yoshiyuki NAKAJIMA, Masao ISHIDA, \\ YASUAKI URA*, YUKIO OCHI*, TADAYOShI MIYAZAKI**, \\ TAKASHI HACHIYA*** AND HAMAO IJICHI***
}

\author{
Department of Internal Medicine, Nantan General Hospital, Yagi, Kyoto, 629-01 \\ * Central Clinical Laboratory, Shiga University of Medical Science, Otsu, Shiga, 520 \\ ** Radiology and *** 2nd Department of Internal Medicine, \\ Kyoto Prefectural University of Medicine, Kyoto, 602
}

\begin{abstract}
TSH-receptor antibody (TRAb) activity and LATS activity of Graves' sera were compared. All of 50 LATS-positive cases were TRAb positive, although only $63 \%$ of LATS-negative cases were TRAb positive.

Binding of ${ }^{125} \mathrm{I}-\mathrm{TSH}$ to the TSH receptors was inhibited dose-dependently by LATS-immunoglobulin. However, no correlation between TRAb activity and LATS activity was observed.

TRAb was positive in 2 LATS-positive cases even when the symptoms of hyperthyroidism were controlled by treatment (antithyroid or radioisotope). The positive TRAb was not changed in 4 Graves' disease patients whose LATS activity had disappeared following antithyroid treatment. These clinical studies show that TRAb is more sensitive than LATS and suggest that LATS may be one of a heterogenous population of antibodies to the TSH receptor in Graves' disease.
\end{abstract}

Long acting thyroid stimulator (LATS) is found in the immunoglobulin $G$ fraction of Graves' serum, and there is considerable evidence that LATS is a thyroid autoantibody (Adams, 1958 ; Kriss et al., 1964 ; Meek et al., 1964; Mckenzie, 1967; Ochi and DeGroot, 1968).

Graves' sera also contain an antibody which inhibits the binding of TSH to thyroid plasma membranes (Manley et al., 1974; Smith and Hall, 1974; Mehdi and Nussay,

Received December 7, 1983
1975). However, this binding was proved not to be specific for thyroid stimulating antibody (TSAb), since it could be inhibited by TSAb-negative sera from patients with Hashimoto's thyroiditis (Endo et al,, 1978). Thus, TSH binding inhibitory immunoglobulin (TBII) has been used as the generic designation of the immunoglobulin which binds to the thyroid receptor.

It has been reported that LATS-immnoglobulin has TBII activity (Ozawa et al., 1975, Schleusener et al., 1975, Claque et al., 1976, Endo et al., 1978, Humphries et al., 
1982 and Koizumi et al., 1982).

Recently a TSH receptor assay kit has been developed by Shewring and Rees Smith (1982). Thus, in the present report we examined the relation between LATS and TRAb activity in patients with Graves' disease and chronological changes in both activities during the course of the disease in 6 patients.

\section{Materials and Methods}

\section{$T R A b$ assay}

The method of Shewring and Rees Smith (1982) was used with reagents supplied by Japan Travenol, LTD. The Practical assay procedure was performed according to the protocol of the assay kit. Normal pool serum $(50 \mu \mathrm{l})$ or serum samples $(50 \mu \mathrm{l})$ were incubated in duplicate with detergent solubilized TSH receptors $(100 \mu \mathrm{l})$ or $1 \%$ Lubrol in Tris- $\mathrm{HCl}$ buffer $(100 \mu \mathrm{l})$ for $15 \mathrm{~min}$ at room temperature. ${ }^{125} \mathrm{I}$-Labelled bovine TSH (about $5,000 \mathrm{cpm}$ ) in $100 \mu \mathrm{l}$ of assay buffer $(50 \mathrm{mM} \mathrm{NaCl}, 10 \mathrm{mM}$ Tris, pH 7.5 containing $1 \mathrm{mg} / \mathrm{ml}$ of bovine serum albumin) was added and incubation continued for $60 \mathrm{~min}$ at $37^{\circ} \mathrm{C}$. The total volume of the assay mixture was $250 \mu \mathrm{l}$. The reaction was stopped by additing $750 \mu \mathrm{l}$ of assay buffer and $1 \mathrm{ml}$ of polyethylene glycol (mol. wt. 6,000) solution $(30 \% \mathrm{w} / \mathrm{v}$ in $1 \mathrm{M} \mathrm{NaCl})$. After mixing the solution well, the tubes were centrifuged $\left(1,500 \times \mathrm{g}\right.$ for $45 \mathrm{~min}$ at $\left.4^{\circ} \mathrm{C}\right)$. TRAb activity was expressed as \% inhibition of labelled
TSH binding to TSH receptors as suggested by Shewring and Rees Smith (1982).

The inhibition of labelled TSH binding to soluble TSH receptors by sera from normal subjects was $2.9 \pm 5.5 \% \quad($ mean $\pm S D, n=20)$. Thus, $2.9 \pm 11.0 \%$ (mean $\pm 2 \mathrm{SD}$ ) was postulated as the normal range. Intra-assay variation and interassay variation of 3 samples with different activities were less than $15.4 \%$ and $21.3 \%$, respectively.

\section{LATS bioassay}

The bioassay was performed by a minor modification of the method of McKenzie (McKenzie, 1967; Ochi et al., 1976). Changes in the blood radioactivity were expressed as a percentage of the initial value. Response less than $200 \%$ at $24 \mathrm{hr}$ could not always be distinguished from the nonspecific responses. Thus, responses between 100 and $200 \%$ were regarded as pseudopositive and those greater than $200 \%$ were considered to be LATS positive. The assay varied from lot to lot, although a potent serum containing LATS was included in each bioassay series. Some fluctuations in assay values appeared to depend on the animal factor and undefined variables. Thus, the LATS activity of all samples was reassayed before this experiment. Especially the LATS activity in the chronological study was confirmed in one assay. The intra-assay variation within each assay was less than $25 \%$.

\section{Preparation of LATS-IgG}

The LATS-IgG fraction was purified from LATS-positive serum by affinity chromatography on Protein A-bound to Sepharose (Ochi et al., 1976).

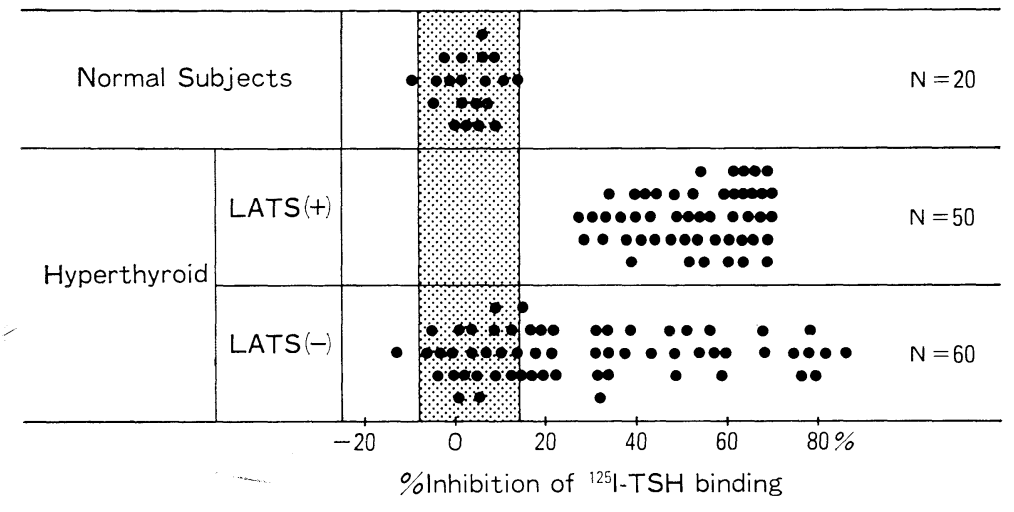

Fig. 1. TRAb activity in sera of Graves' disease. The shaded area represents mean \pm 2 SD of normal subjects. 


\section{Test serum}

All sera of patients with Graves' disease (both untreated and during the treatment) were stored at $-20^{\circ} \mathrm{C}$. 50 cases of LATS-positive sera and 60 cases of LATS-negative sera were examined.

\section{Results}

All LATS-positive sera showed positive TRAb activity (TRAb range, 27.5-71.0\%). TRAb was positive in 38 of 60 patients who were LATS-negative (63\%, TRAb range, 15.0-86.0\%) (Fig. 1).

No significant correlation between TRAb activity and LATS activity was found $(\mathrm{r}=$ 0.037) (Fig. 2).

An inhibitory effect of TSH on the binding of ${ }^{125}$ I-TSH to the receptor was also observed. The binding of ${ }^{125}$ I-TSH was inhibited significantly by more than $50 \mu \mathrm{U} /$ tube of bovine TSH (Armour TSH), but the inhibition by $50 \mu \mathrm{U} /$ tube of human TSH (myxoedema serum) was not significant. This binding was inhibited dose-dependently by not only LATS positive sera but also LATS-IgG fraction (Fig. 3).

The variation in LATS and TRAb activities in the serial serum samples obtained

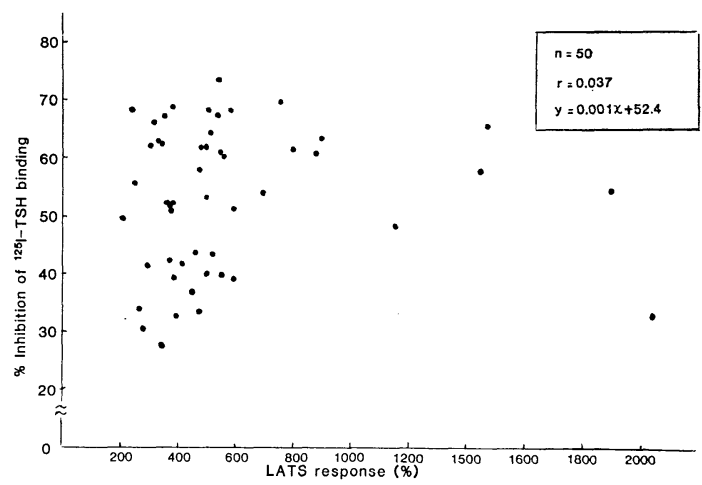

Fig. 2. Relationship between TRAb activity and LATS activity in LATS positive Graves' disease.
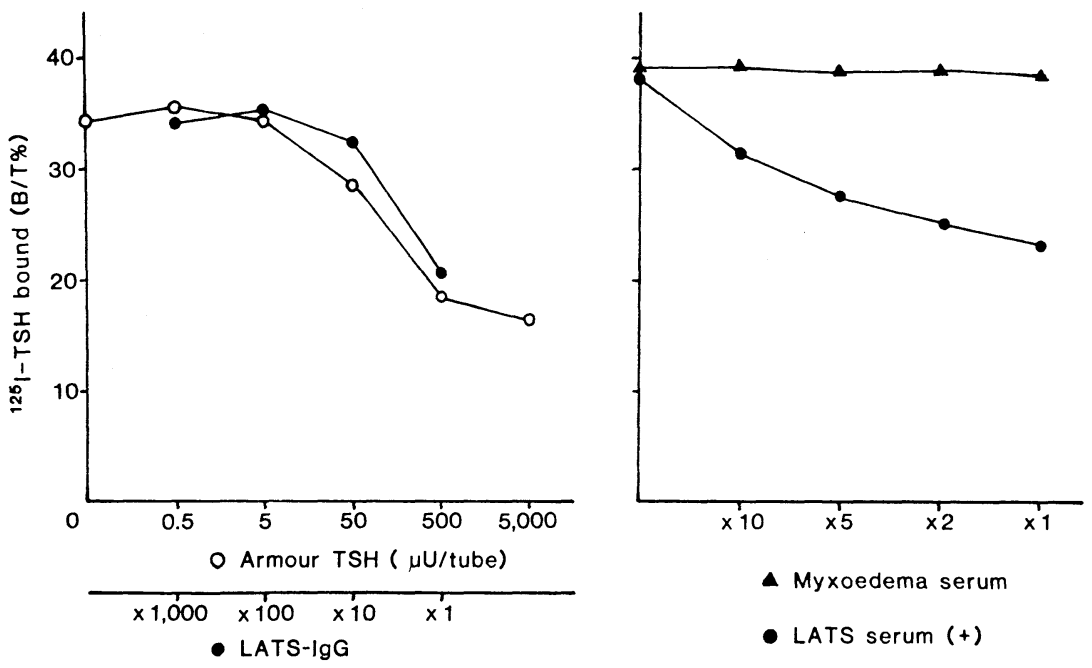

Fig. 3. Effect of TSH (bovine and human) or LATS (serum and IgG fraction) on the binding of ${ }^{125}$ I-TSH to the receptor.

Left: The assay was performed with $50 \mu \mathrm{l}$ of normal human serum containing various amounts of Armour TSH. LATS-IgG fraction equivalent to $50 \mu \mathrm{l}$ of LATS positive serum $(550 \%$ at $24 \mathrm{hr}$ in the bioassay) was diluted with normal human serum.

Right: Serum of LATS positive and myxodematous patients $(1000 \mu \mathrm{U} / \mathrm{ml}$ of TSH) was diluted with normal human serum and then $50 \mu \mathrm{l}$ of each serum was assayed. 
from Graves' disease patients after treatments is shown in Fig. 4 and 5. Patient (a) (age 49) has been treated with large amounts of inorganic iodide since 1978 with the subsidence of hyperthyroidism. Patient (b) (age 60) has been euthyroid since radioisotope therapy in 1977.

In the sera of 4 Graves' disease patients (c-f), LATS had become to negative following antithyroid treatment, but TRAb remained positive in all the patients throughout the period of the experiments.

\section{Discussion}

There are several abnormal thyroid stimulators in serum of patients with Graves' disease, known as LATS, thyroid stimulating immunoglobulin (TSI), thyroid stimulating antibody (TSAb) (Manley et al., 1974, Medhi and Nussay, 1975) and TSH receptor antibody (TRAb) (Smith and Hall, 1974), or TBII (Endo et al, 1978).

One of these stimulators, LATS is re-
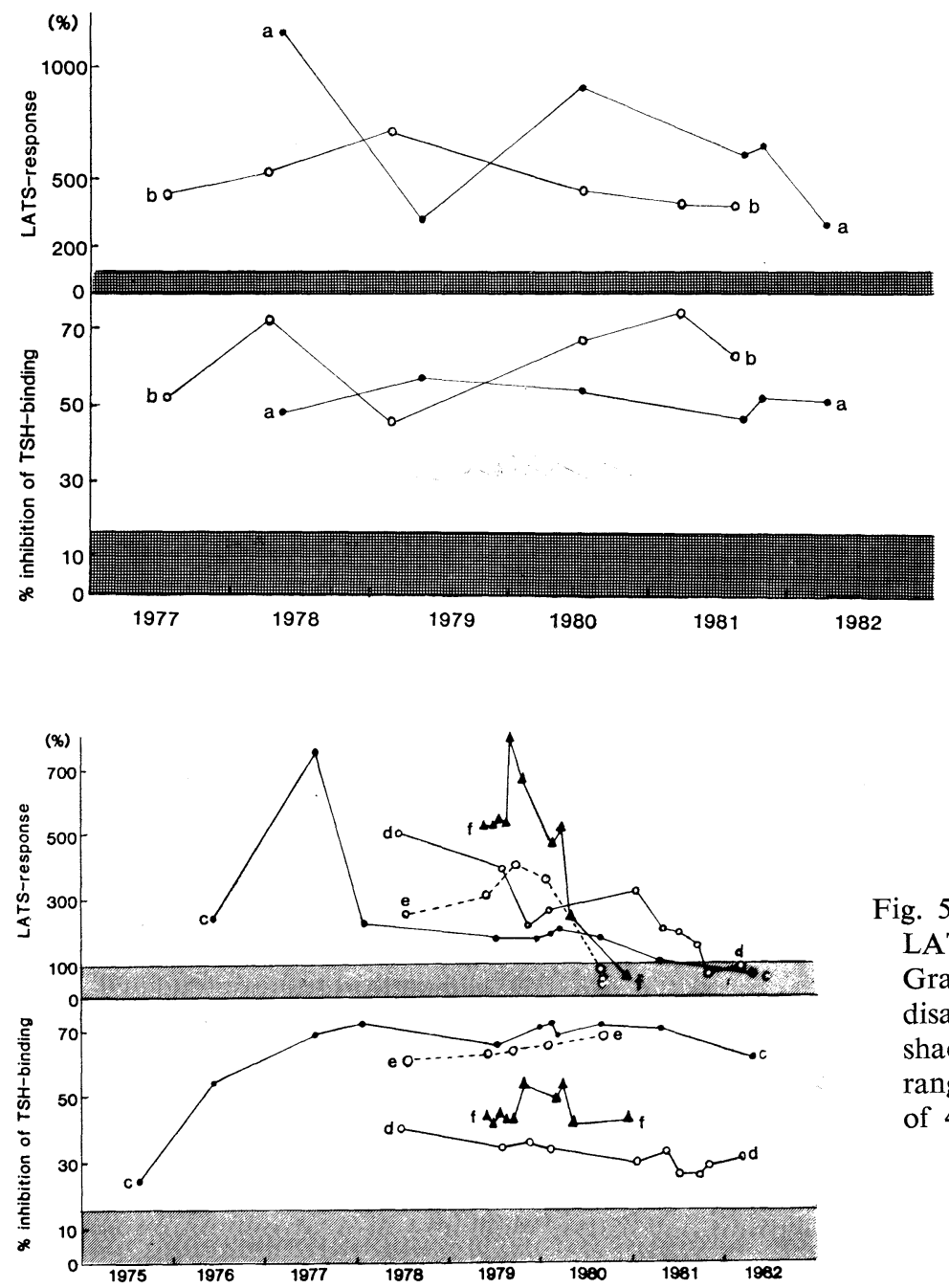

Fig. 4. The chronological activity of LATS and TRAb of sera in Graves' patients with high LATS activity. The shaded area represents the normal range.

LATS and TRAb activity of 2 patients (a and b) is shown.

Fig. 5. The chronological activity of LATS and TRAb of sera in 4 Graves' patients whose LATS had disappeared after treatment. The shaded area represents the normal range. LATS and TRAb activity of 4 patients (c,d,e and $f$ ) is shown. 
garded as mouse thyroid stimulating immunoglobulin (or antibody). Shishiba et al. (1982) and Luttrell (1983) demonstrated a close correlation with measured TBII activity by using mouse and human $\mathrm{TSH}$ receptor preparations. This fact indicates that the thyroid stimulation by LATS is at the same level of receptor binding in both mouse and human thyroid.

In the present study we examined the relation between LATS and TRAb activity with a TSH receptor assay kit using porcine thyroid receptor and ${ }^{125} \mathrm{I}-\mathrm{bTSH}$. In all 50 cases of LATS-positive sera, a positive value greater than $27.5 \%$ (normal range: $-8.1 \%$ $-+13.9 \%$ ) was found. However, in the case of LATS-negative sera, 38 of 60 cases $(63 \%)$ gave a positive value.

A previous report demonstrated that LATS-immunoglobulin inhibited the binding of ${ }^{125}$ I-TSH to thyroid receptor dosedependently (Humphries et al., 1982 and Koizumi et al., 1982). We have also observed a similar dose-dependent inhibition of binding by LATS serum and immunoglobulin. However, we could not find a correlation between LATS and TRAb activity $(r=0.037)$. Similarly no correlation has been reported previously by other laboratories (Schleusener et al., 1975, Claque et al., 1976, Endo et al., 1978). On the contrary, Ozawa et al. (1975) reported a good correlation between LATS activity and TBII values.

Lately, reports using the receptor assay showed that TBII (or TRAb) levels were of some prognostic value because of a tendency for TBII (or TRAb) activity to decrease after long term antithyroid treatment (Fenzi et al., 1979, Teng and Yeung., 1980, Bliddal et al., 1981).

In the present study, changes in TRAb activity were examined chronologically after treatments (antithyroid drug and radioisotope) in 6 Graves' disease patients with positive LATS activity. The positive TRAb activity continued in 2 LATS-positive cases whose thyroid state became euthyroid. The positive TRAb activity remained without change in 4 cases whose LATS activity became negative after subsidence of the hyperthyroid state.

These clinical studies show that the receptor assay is more sensitive than the LATS assay, and suggest that LATS may be a heterogenous population of antibodies with specific binding to TSH receptor.

\section{Acknowledgements}

We wish to thank Dr. Smith, B. R. (Welsh National Univ.) for his valuable comments and for his help in the preparation of this manuscript.

\section{References}

Adams, D. D. (1958). The presence of an abnormal thyroid stimulating hormone in the serum of some thyrotoxic patients. J. Clin. Endocrinol. 18, 699-712.

Bliddal, H., C. Kirkegaard, K. Nielsen and T. Friis (1981). Prognostic value of thyrotropin binding inhibiting immunoglobulins (TBII) in longterm antithyroid treatment, ${ }^{131} \mathrm{I}$ therapy given in combination with carbimazole and in euthyroid ophthalmopathy. Acta Endocrinologica 98, 364-369.

Clague, R., E. D. Mukhtar, G. A. Pyle, J. Nutt, F. Clark, M. Scott, D. Evered, B. R. Smith and R. Hall (1976). Thyroid-stimulating immunoglobulins and the control of thyroid function. J. Clin. Endocrinol. Metab. 43, 550556.

Endo K., K. Kasagi, J. Konishi, K. Ikekubo, T. Okuno, Y. Takeda, T. Mori and K. Torizuka (1978). Detection and properties of TSHbinding inhibitor immunoglobulins in patients with Graves' disease and Hashimoto's thyroiditis. J. Clin. Endocrinol. Metab. 46, 734739.

Fenzi, G., K. Hashizume, C. P. Roudebush and L. DeGroot (1979). Changes in thyroid-stimulating immunoglobulins during antithyroid therapy. J. Clin. Endocrinol. Metab. 48, 572-576.

Humphries, H., S. M. Dirmikis and D. S. Munro (1982). Comparison of human and porcine thyroid membranes for radioreceptor assay of 
bovine thyrotropin and thyrotropin binding immunoglobulins. J. Endocr. 93, 371-380.

Koizumi, Y., M. Zakarija and J. M. McKenzie (1982). Solubilization, purification, and partial characterization of thyrotropin receptor from bovine and human thyroid glands. Endocrinology. 110, 1381-1391.

Kriss, J. P., V. Pleshakov and R. Koblin (1964). Isolation and identification of the long acting thyroid stimulator and its relation to hyperthyroidism and circumscribed pretibial myxedema. J. Clin. Endocrinol. 24, 1005-1028.

Kuzuya, N., S. C. Chiu, H. Ikeda, H. Uchimura, K. Ito and S. Nagataki (1979). Correlation between thyroid stimulators and 3,5,3'triiodothyronine suppressibility in patients during treatment for hyperthyroidism with thionamide drugs : comparison of assays by thyroidstimulating and thyrotropin-displacing activities. J. Clin. Endocrinol. Metab. 48, 706-711.

Luttrell, B. M. (1983). Interaction of the mouse thyrotrophin receptor with thyrotrophin binding inhibitor immunoglobulins. J. Endocr. 96, 481-488.

Manley, S. W., J. R. Bourke and R. W. Hawker (1974). The thyrotropin receptor in guinea-pig thyroid homogenate: general properties. $J$. Endocrinol. 61, 419-436.

Mckenzie, J. M. (1967). The long-acting thyroid stimulator. Its role in Graves' disease. Recent Prog. Horm. Res. 23, 3-46.

Meek, J. C., A. E. Jones., V. J. Lewis and W. P. VanderLaan (1964). Characterization of the long acting thyroid stimulator of Graves' disease. Proc. Natl. Acad. Sci. U.S.A. 52, 342349.

Mehdi, S. Q. and S. S. Nussey (1975). A radioligand receptor assay for the long-acting thyroid stimulator: Inhibition by the long-acting thyroid stimulator of the binding of radioiodinated thyroid-stimulating hormone to human thyroid membranes. Biochem. J. 145, 105-111.

Ochi, Y. and L. J. DeGroot (1972). Studies on the immunological properties of LATS. Endocrinology. 83, 845-854.

Ochi, Y., M. Yoshimura, T. Hachiya and T. Miyazaki (1976). Immunological studies on LATS-immunoglobulin by the reaction with staphylococcal protein. Endocrinol. Japon. 23, 183-186.

Ozawa, Y., R. M. B. Maciel, I. J. Chopra, D. H. Solomon and G. N. Beall. (1979). Relationships among immunoglobulin markers in Graves' disease. J. Clin. Endocrinol. Metab. 48, 381-387.

Schleusener, H., P. Kotulla, F. Adlkofer, S. S. Nussey and S. Q. Mehdi (1975). Clinical application of a radioreceptor assay for thyroid stimulators. Horm. Metab. Res. 7, 360-361.

Shewring G. and B. R. Smith (1982). An improved radioreceptor assay for TSH receptor antibodies. Clin. Endocrinol. 17, 409-417.

Shishiba, Y., Y. Ozawa, N. Ohtsuki and T. Shimizu (1982). Discrepancy between thyroidstimulating and thyrotropin binding inhibitory activities of Graves' immunoglobulin Gs assessed in the mouse. J. Clin. Endcrinol. Metab. 54, 858-862.

Smith, B. R. and R. Hall (1974). Thyroidstimulating immunoglobulin in Graves' disease. Lancet. II. 427-430.

Teng, C. S. and T. T. Yeung (1980). Changes in thyroid-stimulating antibody activity in Graves' disease treated with antithyroid drug and its relationship to relapse: a prospective study. J. Clin. Endocrinol. Metab. 50, 144-147. 